\title{
Larval Settlement of the Japanese Flounder on Sandy Beaches of the Yatsushiro Sea, Japan
}

\author{
Subiyanto, ${ }^{* 1}$ Ikuo Hirata, ${ }^{* 2}$ and Tetsushi Senta*3 \\ (Received December 8, 1992)
}

\begin{abstract}
Larval settlement of the Japanese flounder was studied on six beaches of the Yatsushiro Sea. The settlement was seen from early March to late May, with a peak occurring from mid-March to late April. The population density was much higher along the beach, 15 to $70 \mathrm{~cm}$ deep. compared to waters $3-9 \mathrm{~m}$ deep. Comparison of the catches of newly settled larvae and older juveniles at each sampling site suggeted the following: the incidence of larval settlement on a beach is primarily governed by its location in relation to the pattern of the inflowing current at flood tide, whereas the density of food organisms and the quality of sediment affect the establishment of settlement, the survival rate, and the growth of the larvae.
\end{abstract}

With the aim of increasing the catch of the Japanese flounder Paralichthys olivaceus in the Yatsushiro Sea, ranging annually around 60-70 tons, the release of reared juveniles was started as a joint project of the Kumamoto Prefectural Government and Federation of Fishermen's Unions in 1980. In 1989, ca. 420,000 reared juveniles were released. However, hardly any thing had been known about the early life history and ecology of wild fish in this sea, and the sites of release had been decided mostly from an administrative viewpoint.

To establish a scientific foundation for the sea farming project in the Yatsushiro Sea, we started a study on the larval and juvenile ecology of the fish in 1989, and reported on the seasonal and geographical occurrences of pelagic larvae. ${ }^{\text {) }}$ In this paper the larval settlement of the fish is reported, based on field data collected in 1989 1991.

\section{Study Sites and Methods}

The Yatsushiro Sea is an inlet of ca. $1,200 \mathrm{~km}^{2}$, with a tidal range during the spring tide reaching ca. $4 \mathrm{~m}$ in the innermost part and ca. $3 \mathrm{~m}$ in the southern part. Sandy and muddy tidal flats of ca. $46 \mathrm{~km}^{2}$ develop in the northern part. ${ }^{2)}$ Com- paratively speaking, the tidal flats of the Amakusa Islands are all small, seldom exceeding 5 ha.

The settled larvae and juveniles were collected with a push-net on six beaches, as below (Fig. 1).

Satsukihama beach, Ushibuka: with a tidal flat of $500 \times 50 \mathrm{~m}$, facing the open sea; Tsurugahama beach, Ashikita, $250 \times 30 \mathrm{~m}$, adjoining a small river; Donto beach, Hinoshima: $450 \times 30 \mathrm{~m}$; Kongo beach, Yatsushiro: $9.0 \times 2.4 \mathrm{~km}$, situated close to the edge of the water channel of the Minami River; Machigata beach, Matsushima: $130 \times 80 \mathrm{~m}$, facing the Utonoseto Straits; Kohama beach, Izumi: $4.0 \times 0.6 \mathrm{~km}$, adjoining a small river.

For covenience, the respective beaches are designated by their locale in this paper.

The bottom sediment consisted of coarse sand at Ashikita, and of fine sand on the other beaches (Table 1). The general pattern of tidal currents and monthly water temperatures from January to June were shown in our previous paper. ${ }^{1}$

The surveys were conducted in three seasons during Years 1989-1991, except for Izumi, where sampling was started in the middle of 1991 season. Collections were made around low water spring tide during the daytime; monthly from April to June in 1989 and semimonthly from March to Jne in 1990 and 1991.

The sampling gear was almost the same as the

*1 Department of Fisheries, Faculty of Animal Husbandry, Diponegoro University, Semarang, Indonesia (スビヤント: ディポネコロ丈学).

*. Fisheries Research Center of Kumamoto Prefecture, Ooyano, Kumamoto 869-36, Japan (平田郁 㚘：能本罢水應研究七ン夕一).

*3 Faculty of Fisheries, Nagasaki University, Bunkyomachi, Nagasaki 852, Japan（千田暂資: 舆詴 大学水麿学部). 


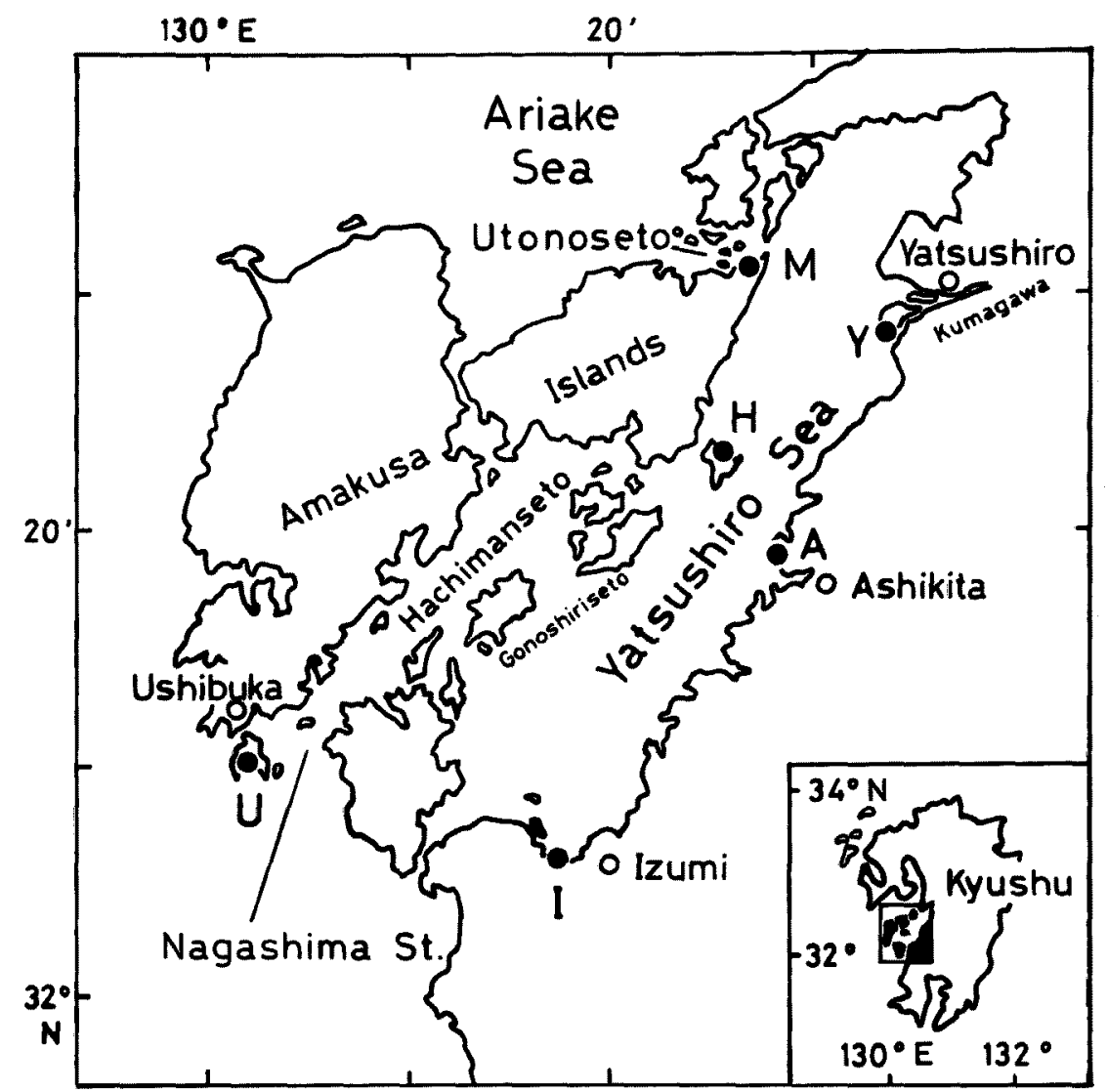

Fig. 1. A map showing the location of sampling sites (solid dots) for settled juveniles of the Japanese flounder along beaches.

The names of the beaches are abbreviated as A: Ashiktta, H: Hihoshima, I: Izumi, M: Matsushima, U: Ushibuka, and $\mathrm{Y}$ : Yatsushiro.

Table 1. Values of various characteristics of the bottom sediment at the surveyed beaches of the Yatsushiro Sea

\begin{tabular}{cccccc}
\hline Parameter* & Ushibuka & Ashikita & Hinoshima & Yatsushiro & Matsushima \\
\hline Md $\Phi$ & 2.0 & 0.5 & 2.1 & 2.3 & 2.6 \\
Qd $\Phi$ & 2.0 & 0.5 & 2.2 & 2.3 & 2.7 \\
Skq $\Phi$ & -0.1 & -0.1 & 0.0 & 0.0 & 0.1 \\
K $_{G}$ & 1.0 & 0.9 & 1.1 & 1.0 & 1.3
\end{tabular}

* Md $D$ : the diameter in phi unit corresponding to the $50 \%$ mark on the cumulative curve; Qd $\phi:$ phi quartile deviation $=(\phi 75-\phi 25) / 2$; Skq $\Phi$ : phi quartile skewnes $=(\phi 25+\Phi 75-2 \Phi 50) / 2 ; \mathrm{K}_{\mathrm{G}}$ : kurtosis $\left.=(\phi 95-\phi 5) / 2.44(\phi 75-\Phi 25),{ }^{3}\right)$

Riley push-net ${ }^{4}$ in general construction; a bag net $255 \mathrm{~cm}$ in length with a $2 \times 2-\mathrm{mm}$ mesh is attached to a beam frame 150 by $30 \mathrm{~cm}$. We call the net the R-H push-net.5) The net was pushed along $100 \mathrm{~m}$ of the beach within wading depths, $15-75 \mathrm{~cm}$, at a speed of ca. $35 \mathrm{~m}$ per minute. As a rule, this operation was repeated three times per sampling time on each beach, but operations were increased or decreased depending on the size of the tidal flat or the weather conditions. Thus, the efforts for collection differed according to the place and the month (Table 2).

Additional collections with a small beam trawl which was of the same dimension as the push-net 
Table 2. Operation records of push-net for larval and juvenile Japanese flounder at six beaches of the Yatsushiro Sea

\begin{tabular}{|c|c|c|c|c|c|c|c|c|}
\hline \multirow{2}{*}{ Year } & \multirow{2}{*}{ Month } & \multicolumn{6}{|c|}{ Beaches } & \multirow{2}{*}{$\begin{array}{l}\text { Total no } \\
\text { operation }\end{array}$} \\
\hline & & $\mathrm{U}$ & A & $\mathrm{H}$ & $\mathrm{Y}$ & $\mathrm{M}$ & I & \\
\hline \multirow[t]{3}{*}{1989} & April & 4 & 2 & 6 & 8 & 3 & 0 & 23 \\
\hline & May & 6 & 2 & 6 & 8 & 3 & 0 & 25 \\
\hline & June & 7 & 5 & 6 & 8 & 2 & 0 & 28 \\
\hline \multirow[t]{4}{*}{1990} & March & 16 & 11 & 8 & 16 & 5 & 0 & 56 \\
\hline & April & 11 & 19 & 9 & 16 & 7 & 0 & 62 \\
\hline & May & 13 & 15 & 8 & 16 & 8 & 0 & 60 \\
\hline & June & 10 & 10 & 8 & 8 & 4 & 0 & 40 \\
\hline \multirow[t]{4}{*}{1991} & March & 16 & 10 & 16 & 14 & 12 & 0 & 68 \\
\hline & April & 16 & 10 & 16 & 11 & 8 & 6 & 67 \\
\hline & May & 20 & 18 & 24 & 15 & 8 & 12 & 97 \\
\hline & June & 0 & 6 & 8 & 0 & 3 & 6 & 23 \\
\hline Total & & 119 & 108 & 115 & 120 & 63 & 24 & 549 \\
\hline
\end{tabular}

were made at three depths of ca. 3, 5, and $8 \mathrm{~m}$ off Ashikita in March and April 1991. At each depth, the net was towed for a distance of $200 \mathrm{~m}$ parallel to the beach line.

The specimens were preserved in $5 \%$ neutral formalin. The larvae and juveniles were staged following Minami ${ }^{(2)}$ and Goto et al. ${ }^{7}$

\section{Results}

\section{General Accounts of Specimens Obtained}

A total of 2,255 individuals of larval and juvenile Japanese flounder were caught. Most of the specimens were smaller than $16 \mathrm{~mm} \mathrm{SL}$ with a prominent mode at $12-14 \mathrm{~mm}$, whereas larger fish up to $80 \mathrm{~mm} \mathrm{SL}$ were caught in small numbers (Fig. 2). Juveniles of stages $I_{1}-I_{3}$, which are considered to be newly settled, accounted for $61 \%$ of the total catch. No reared juvenile occurred in our samples.

\section{Seasonal Occurrence of Newly Settled Larvae}

Newly settled larvae at stages $\mathrm{G}-\mathrm{I}_{3}$ were much more abundant and occurred for a longer period at Ashikita than at the other places (Fig. 3). Here the settling season in 1991 lasted from early March to the end of May, with a prominent peak at the beginning of April, whereas in 1990 the larvae were less abundant and were collected only until early May. The larvae were second most abundant at Matsushima, where their seasonal occurrences in 1990 and 1991 were almost the same, with two peaks at the end of March and the end of April,

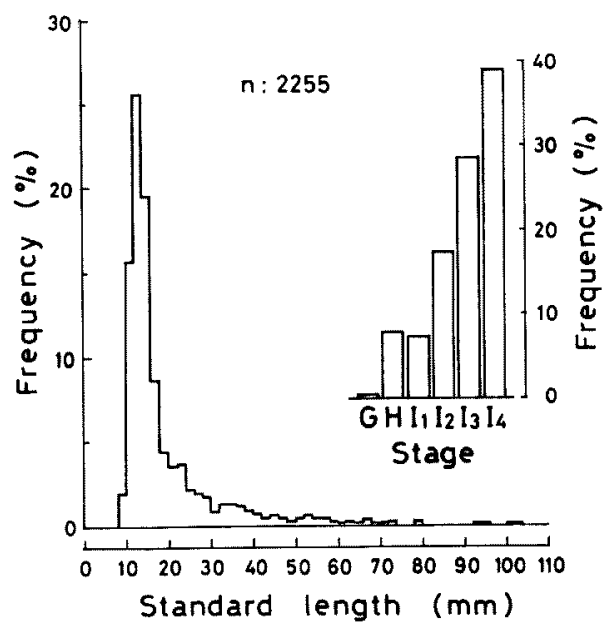

Fig. 2. Body length distribution and stage composition of Japanese flounder collected in 1989-1991.

Stages: $\mathrm{G}$, mid metamorphosing stage; $\mathbf{H}$, late metamorphosing stage; I, nearly or completely metamorphosed stage $\left(I_{1}\right.$, pectoral fin rays rudimental; $I_{2}$, pectoral fin rays differentiating; $\mathbf{I}_{3}$, upper pectoral fin rays elongated; $\mathbf{I}_{4}$, pectoral fin formation completed) (after Minami ${ }^{(3)}$ and Goto et al. ${ }^{7)}$ ).

and they occurred for a slightly shorter period than at Ashikita.

The abundance of newly settled larvae at Ushibuka, Hinoshima, and Yatsushiro was much less, rarely exceeding five fish per operation even at the 


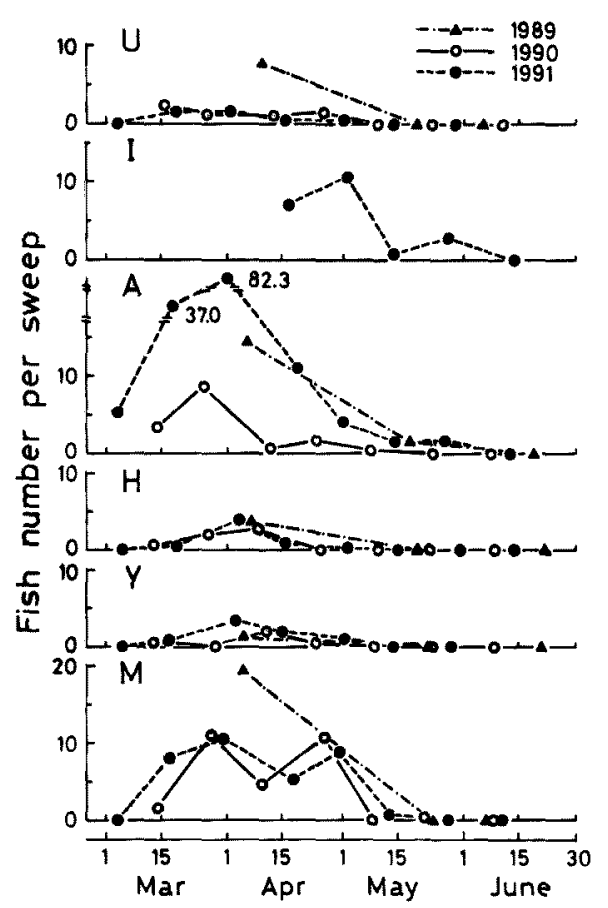

Fig. 3. Seasonal occurrence of newly settled larvae (stages $\mathrm{G}-\mathrm{I}_{3}$ ) in wading depths, 15-75 $\mathrm{cm}$ deep, on six beaches.

The names of beaches are abbreviated as in Fig. 1.

peak abundance in the first half of April. The settling season at Hinoshima and Yatsushiro started later and ended earlier than on the other beaches.

Seasonal Increase of Older Juveniles and Their Growth

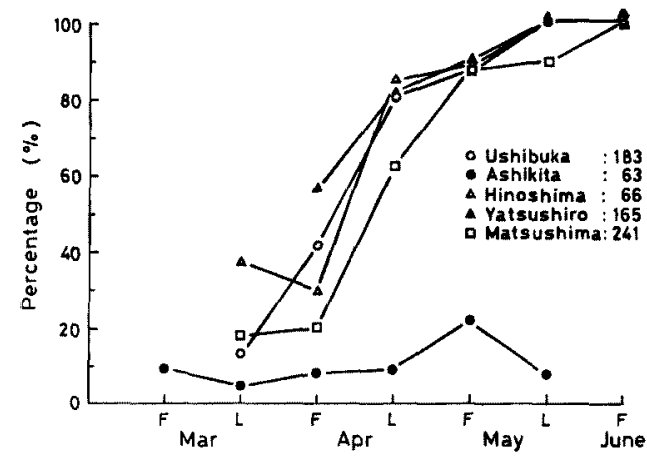

Fig. 4. Seasonal increase in older juveniles $\left(\mathbf{I}_{4}\right)$ in percentage of the total catch on the five beaches.

The catches from 1989 to 1991 are combined, and sampling dates for one month were grouped into the former $(\mathrm{F})$ and latter half $(\mathrm{L})$.

A very small catch of $I_{4}$ juveniles (63 fish) at Ashikita contrasted strikingly with the marked abundance of newly settled larvae (725 fish of the stages $\mathrm{G}^{-} \mathrm{I}_{3}$ ) on this beach. Both newly settled larvae and older juveniles were much more abundant within wading depths than in deeper waters beyond (Table 3). At the other places, percentages of $\mathrm{I}_{4}$ juveniles increased rapidly from the middle of March through the end of April (Fig. 4). Seasonal changes in length compositions of $\mathrm{I}_{4}$ juveniles caught at Ushibuka, Yatsushiro, and Matsushima are summarized in Fig. 5. The smallest fish of the $\mathrm{I}_{4}$ stage obtained was $13.9 \mathrm{~mm}$ SL while the largest was $102.9 \mathrm{~mm} \mathrm{SL}$. The mode in length composition shifted toward the larger side by $6 \mathrm{~mm}$ in Ushibuka and Matsushima during the period of one month from the end of March to the end of April, but this was not clear

Table 3. Depth distribution of the newly-settled (stages $\mathrm{G}-\mathrm{I}_{3}$ ) and older (stage $\mathrm{I}_{4}$ ) juveniles of the Japanese flounder along and off Ashikita beach during main settling season in 1991

\begin{tabular}{lccccc}
\hline \multirow{2}{*}{ Date } & $\begin{array}{c}\text { Depth } \\
(\mathrm{m})\end{array}$ & $\begin{array}{c}\text { Number of } \\
\text { operations }\end{array}$ & \multicolumn{2}{c}{ Indiv. no. collected } & $\begin{array}{c}\text { Indiv. no. } \\
\text { per } 150 \mathrm{~m}^{2}\end{array}$ \\
\hline Mar. 18 & $0.15-0.7$ & 4 & 137 & $\mathrm{I}_{4}$ & 11 \\
& $2.7-3.2$ & 2 & 0 & 10 & 37.00 \\
& $4.7-5.3$ & 2 & 2 & 0 & 0.00 \\
Apr. 19 & $7.8-9.0$ & 2 & 1 & 0 & 0.50 \\
& $0.15-0.7$ & 6 & 66 & 8 & 0.25 \\
& $2.7-3.2$ & 2 & 2 & 0 & 12.30 \\
& $4.7-5.3$ & 2 & 1 & 0 & 0.50 \\
& $7.8-9.0$ & 2 & 0 & 0 & 0.25 \\
\hline
\end{tabular}

The sweeping area per operation was $150 \mathrm{~m}^{2}$ at the depth $0.15-0.7 \mathrm{~m}$ and $300 \mathrm{~m}^{2}$ at the other depths. 


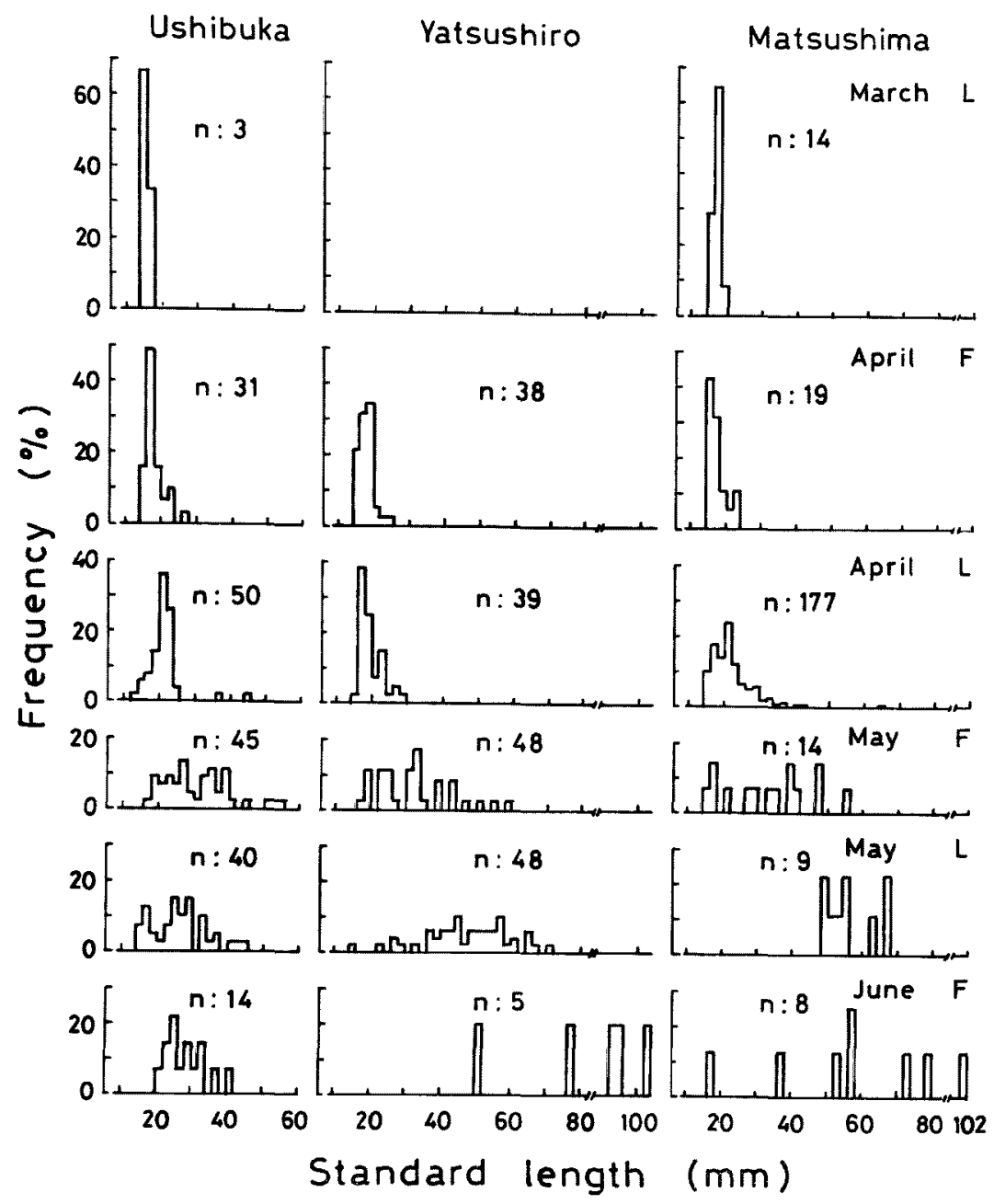

Fig. 5. Seasonal changes in body length distribution of juveniles of stage $I_{4}$ at Ushibuka, Yatsushiro, and Matsushima beaches.

$F$ and $L$, the former and latter half of a month.

in Yatsushiro. Although no marked mode was seen in size frequency distribution in the three places in May and June, the size of the largest specimen obtained at Yatsushiro and Matsushima increased with the advance of the season.

\section{Feeding Habit}

Diets of 280 specimens were examined. About $26 \%$ of the stomachs were empty. The ratio of empty stomachs tended to be higher in the smallest size class, $10.0-19.9 \mathrm{~mm} \mathrm{SL}$, especially markedly at Ashikita where almost $80 \%$ of the fish had empty stomachs (Table 4).
The food of specimens smaller than $20 \mathrm{~mm} \mathrm{SL}$ mainly consisted of mysids, with copepods and amphipods occurring at much lower frequencies and in smaller numbers (Fig. 6). The fish began to feed on other fishes when they reached $25 \mathrm{~mm}$ $\mathrm{SL}$, and the importance of fish as food rapidly increased with the growth of the fish. Cannibalism was often seen in juveniles larger than $50 \mathrm{~mm}$ SL; a juvenile of $54.0 \mathrm{~mm} \mathrm{SL}$ was found to have fed on a conspecific juvenile of $25.0 \mathrm{~mm}$ SL.

Despite the general tendency mentioned aboove, the main food organisms differed from beach to beach. Table 5 compares the food composition 
Table 4. Percentage occurrences of empty stomachs of Japanese flounder by sizes of the fish and by beaches

\begin{tabular}{|c|c|c|c|c|c|c|c|c|c|c|c|c|}
\hline \multirow{2}{*}{$\begin{array}{l}\text { Ranges of } \\
\text { SL (mm) }\end{array}$} & \multicolumn{6}{|c|}{ No. of fish examined } & \multicolumn{6}{|c|}{ Percentage of empty stomach } \\
\hline & $\mathrm{U}$ & A & $\mathbf{H}$ & $Y$ & M & I & $\mathrm{U}$ & A & $\mathrm{H}$ & $Y$ & M & $\mathrm{I}$ \\
\hline $10.0-19.9$ & 11 & 56 & 17 & 15 & 16 & 10 & 9.1 & 78.6 & 47.1 & 33.3 & 25.0 & 0.0 \\
\hline $20.0-29.9$ & 12 & 8 & 11 & 11 & 11 & 10 & 16.7 & 0.0 & 9.1 & 9.1 & 0.0 & 0.0 \\
\hline $30.0-39.9$ & 11 & 2 & 1 & 10 & 6 & 10 & 9.1 & 0.0 & 0.0 & 0.0 & 0.0 & 0.0 \\
\hline $40.0-49.9$ & 2 & 1 & - & 10 & 4 & 4 & 0.0 & 0.0 & - & 0.0 & 0.0 & 0.0 \\
\hline $50.0-59.9$ & 3 & - & 2 & 11 & 4 & 2 & 33.3 & - & 0.0 & 9.1 & 25.0 & 0.0 \\
\hline $60.0-69.9$ & - & - & - & 4 & 1 & - & - & - & - & 0.0 & 0.0 & - \\
\hline $70.0-\mathrm{Up}$ & - & - & - & 3 & 1 & - & - & - & - & 0.0 & 0.0 & - \\
\hline
\end{tabular}

Note: Dashes denote absence of specimens.

Beach names are abbreviated as in Table 2 and Fig. 1.
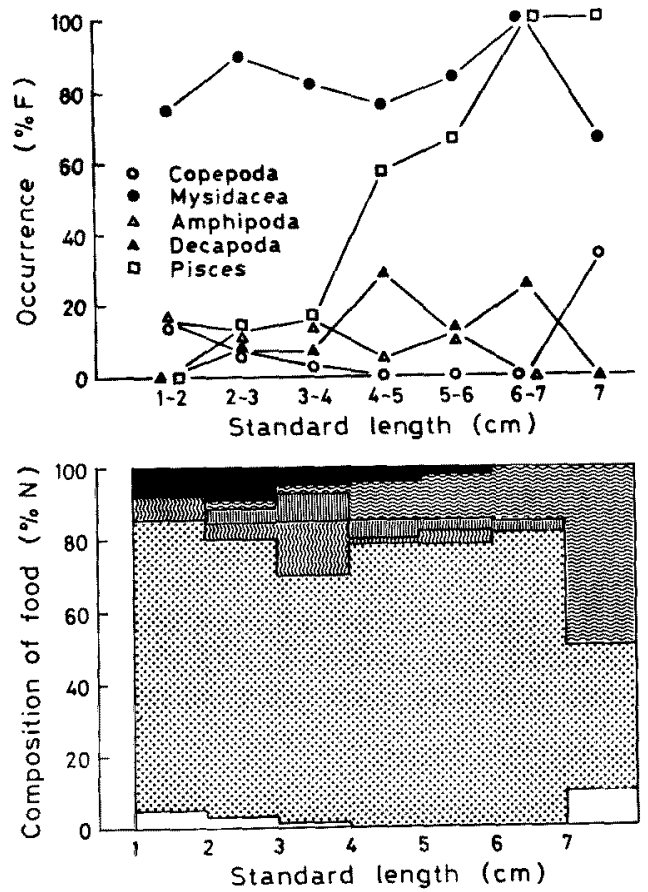

$\square$ Copepoda $\begin{aligned} & \text { Mysidacea } \\ & \text { Pisces }\end{aligned}$

Fig. 6. Relative importance of food organisms categorized into six groups according to length of the Japanese flounder.

Top: frequency of occurrence method, bottom: numerical method.
Table 5. Comparison of the diets of the juvenile Japanese flounder smaller than $20 \mathrm{~mm} \mathrm{SL}$ caught at three beaches of the Yatsushiro Sea in 1991

\begin{tabular}{lccc}
\hline Food iltems & Ashikita & Yatsushiro & Matsushima \\
\hline Copepoda & 76.0 & 5.5 & 0.0 \\
Mysidacea & 8.5 & 86.1 & 98.8 \\
Amphipoda & 11.9 & 5.0 & 0.0 \\
Others & 3.6 & 3.4 & 1.2 \\
\hline
\end{tabular}

The relative numbers $(\%)$ of individuals of food organisms are shown.

of fish smaller than $20 \mathrm{~mm}$ SL caught on three beaches. Although the fish collected at Yatsushiro and Matsushima fed almost exclusively on mysids, those at Ashikita took mainly copepods. This must be caused by the difference in the density of mysids on the three beaches. The abundance of mysids, dominated by Neomysis awatschensis and Archaeomysis vulgaris, was much lower at Ashikita than on the other beaches during the main settling season (Table 6).

\section{Discussion}

Surveys on pelagic larvae in and around the Yatsushiro Sea ${ }^{1 /}$ revealed that the recruitment of fish in the inlet mostly depended on pelagic larvae spawned outside the Yatsushiro Sea, i.e. in the waters west of the Amakusa Islands. They immigrate into the Yatsushiro Sea through the Nagashima Straits and via Hachimanseto. After

Table 6. Weights of mysids (g) simultaneously collected with fish by push-net at surveyed beaches in late March to early April and in mid-April in 1991

\begin{tabular}{cccccc}
\hline Period & Ashikita & Hinoshima & Yatsushiro & Matsushima & Izumi \\
\hline L. Mar,-e. Apr. & 0.31 & 2.74 & 75.00 & 3.85 & - \\
Mid-April & 0.11 & 3.00 & 9.75 & 6.97 & 6.98
\end{tabular}


passing the Nagashima Straits, the inflowing water during a flood tide passes through Gonoshiriseto into the Yatsushiro Sea proper, with the main current heading for Ashikita. ${ }^{12}$ This may be the reason for the abundance of newly settled larvae on this beach. Larval immigration, though less abundant, from the Ariake Sea through Utonoseto was also observed. ${ }^{13}$ and this may explain why the newly settled larvae were abundant at Matsushima next to Ashikita.

The larval settlement at Yastsushiro and Hinoshima started later and ended earlier than on the other beaches. These two beaches are located furthest away from the entrances of the larval immigration, and the water temperature in February off these beaches was lower than on the others by $1.5^{\circ} \mathrm{C}$ or more. ${ }^{1}$ To settle on these beaches the pelagic larvae need not only a longer time to reach it, but also a longer time to complete metamorpholsis because of a low water temperature. ${ }^{8,8)}$

The beach at Ashikita consisted of coarse sand, whereas Shijiki Bay and Yanagihama, where settlement in large numbers has also been reported, have a bottom of fine sand. $\left.{ }^{a}{ }^{10}\right)$ The density of mysids, which are generally reported to be the main food item of the settled juvenile flounder, ${ }^{11,12}$ ) was much lower at Ashikita than on the other beaches studied. These facts, together with the fact that newly settled larvae were most abundant at Ashikita, suggest that the primary factor governing the abundance of newly settled larvae on a beach of the Yatsushiro Sea is the location of the beach in relation to the pattern of the tidal current which carries the immigrating pelagic larvae. The sediment size and density of food organisms seem to be less important factors, although they are important for the survival of juveniles thereafter.

A rapid decrease in the abundance of settled larvae in a short period is a common phenomenon observed at almost every location studied so far. It is postulated that this rapid decrease is caused either by the dispersal of juveniles to deeper waters, or an extremely high mortality due to predation or starvation. ${ }^{12-14}$ Samplings at depths of 5 and $10 \mathrm{~m}$ off a coast of Fukuoka Prefecture by Imabayashi ${ }^{15}$ ) suggested the possible movement of juveniles from beaches to deeper water with their growth.

At Ashikita the scarcity of older juveniles contrasted strikingly with the abundance of newly settled larvae. Samplings with beam trawl pro- vided negative evidence for larval dispersion to deeper areas shortly after settlement. On the other hand, mysid abundance was extremely low and larvae with empty stomachs were observed at a much higher ratio at Ashikita than on the other beaches. Tanda ${ }^{10}$ found that a juvenile of $23.0 \mathrm{~mm}$ could not burrow into the sand when the grain size exceeded $0.5 \mathrm{~mm}$. Therefore, the newly settled larvae are thought to have greater difficulty in burrowing and to be more vulnerable to predation at Ashikita, where the median diameter of sediment was $0.7 \mathrm{~mm}(0.5$ in $\Phi$ units). It is possible that the mortality due to a dearth of food and high predation pressure caused the rapid disappearance of settled larvae from this beach, as suggested by Fujii et al. ${ }^{14}$ in Shijiki Bay. It is, however, also possible that the disappearance resulted from the return of once-settled larvae to pelagic life due to a shortage of food at Ashikita, since starvation is known to cause pelagic swimming of newly settled larvae of Japanese floun$\operatorname{der}^{\left.13,1^{12}\right)}$ as well as of plaice Pleuronectes platessa. ${ }^{18)}$

Tidally related horizontal movements have been well documented in O-group plaice along European beaches. ${ }^{18-212}$ Especially in the Wadden Sea, they migrate for as for as $1,000 \mathrm{~m}$ over a tidal flat with tides in search of food. ${ }^{203}$ Catch records by various kinds of small-scale fishing gear such as set nets and gill nets operated in intertidal and subtidal zones off Yatsushiro ${ }^{22)}$ suggested such a tidal migration of $\mathbf{O}$-group Japanese flounder. However, further study on this aspect is needed.

Berghahn $^{23}$ made detailed observations on newly settled plaice in the Wadden Sea: spatial segregation of juveniles from predators including older conspecies; size of juveniles at commencement of tidal migration; behavior of juveniles in high-lying tidal pools (puddles); significance of abiotic factors in puddles; "exodus" from puddles and drainages; predation by wading birds, etc. Hardly any such obervations have ever been made on Japanese flounder. Vast tidal flats in the $\mathrm{Ya}$ tsushiro Sea, and also in the Ariake Sea and the Seto Inland Sea, would provide an ideal place for such studies.

\section{Acknowledgements}

We express our gratitude to Mr. T. Uramoto, the former director, and staff of the Kumamoto Fisheries Research Center for their encouragement and assistance during this study. Appreci- 
ation is extended to S. Kurioka and H. Yamaya who helped us in the field work during the present studies.

\section{References}

1) Subiyanto, I. Hirata, and T. Senta: The occurrence of pelagic larvae of the Japanese flounder in the Yatsushiro Sea and adjacent waters, Japan. Nippon Suisan Gakkaishi, 58, 229-234 (1992).

2) Anonymous; in "The Geographical Dictionary of Japan, Vol. 43, Kumamoto-ken", Kadokawa Shoten, Tokyo, 1987, p. 1092. (in Japanses)

3) A. C. Brown and A. McLachlan: Ecology of sandy shores. Elsevier, Amsterdam, 1990, pp. 7-9.

4) J, D. Riley: The Riley push-net, in "Methods for the Study of Marine Benthos" (ed, by N. A. Holmes and A. S. McIntyre), Blackwell Scientific Publication, Oxford, 1971. pp. 286-290.

5) M. H. Amarullah and T. Senta: The R-H push-net, a gear for study of juvenile flatfishes along the beach. Bull. Fac. Fish. Nagasaki Univ., (65), 9-14 (1989).

6) T. Minami: The early life history of a flounder Paralichthys olivaceus, Nippon Suisan Gakkaishi, 48, 1581-1588 (1982),

7) T. Goto, H. Sudo, M. Tomiyama, and M. Tanaka: Setting period of larvae and juveniles of Japanese flounder Paralichthys olivacews in Shijiki Bay, Hirado island. Nippon Suisan Gakkaishi, 55, 9-16 (1989).

8) T. Seikai, J. B. Tanangonan, and M. Tanaka: Temperature influence on larval growth and metamorphosis of the Japanese flounder Paralichthys olivaceus in the laboratory. Nippon Suisan Gakkaishi, 52, 977-982 (1986).

9) J. B. Tanangonan, M. Tagawa, M. Tanaka, and T. Hirano: Changes in tissue thyroxine level of metamorphosing Japanese flounder Paralichthys olivaceus reared at different temperatures. Nippon Suisan Gakkaishi, 55, 485-490 (1989).

I0) M. H. Amarulfah, Subiyanto, T. Noichi, K. Shigemitsu, Y, Tamamoto, and T. Senta: Settlement of larval Japanese flounder (Paralichthys olivaceus) along Yanagihama Beach, Nagasaki Prefecture, Bull. Fac. Fish. Nagasaki Univ., (70), 7-12 (1991).

11) H. Sudo, M. Azeta, and R. Ikemoto: Distribution and feeding habit of juvenile and young Japanese flounder in Shijiki Bay. Progress Rep. Mar. Ranching, Flatfishes, (1) (S. 57 and 58), Seikai Reg. Fish. Res. Lab., 1985, pp. 25-30.

12) M. H. Amarullah: Ecological study of juvenile fatfishes, especially of Japanese founder, Paralichlitys otivaceus (Temminck et Schlegel), occurring along sandy beaches of the western coast of Kyushu. Doctoral thesis, Nagasaki University, Nagasaki, 1989, 75 p.

13) M. Tanaka, T. Goto, M. Tomiyama, and H. Sudo: Immigration, settlement and mortality of flounder (Paralichthys olvaceus) larvae and juweniles in a nursery ground, Shijiki Bay, Japan. Neth, S, Sen Res., 24, 57-67 (1989).

14) T. Fujit, H. Sudo, M. Azeta, and M. Tanaka: Settling process of larvae and juveniles of Japanese flounder, in Shijiki Bay, Hirado Island. Nippon Suisan Gakkaisht, 55, 17-23 (1989).

15) H. Imabayashi: Settling mechanism of larvae of bastard halibut, Paralichthys olivaceus, in the nursery ground, estimated from the size distribution. Nippon Suisan Gakkaishi, 46, 419-426 (1980).

16) M. Tanda: Ability of creeping into sand by hatcheryreared 'Hirame' Paralichthys olivacews. Suisanzoshoku, 36, 21-25 (1988).

17) M. Tanaka: Occurrence, recruitment, settlement and mortality of Japanese flounder larvae and juveniles in Shijiki Bay. Fish. Eng., 24, 33-44 (1988)

18) F. Creutzberg, A.T. G.W. Eltink, and G.J. Van Noort: The migration of plaice larvae Pleuronectes platessa into the western Wadden Sea, in "Physiology and Behaviour of Marine Organisms, Proceedings of the 12th European Symposium on Marine Biology" (ed. by D. S. McLusky and A. J. Berry), Pergamon Press, Oxford, 1978, pp. 243-251.

19) R. N. Gibson: The intertidal movements and distribution of young fish on a sandy beach with special reference to the plaice (Pleuronectes platessa L.). J. exp. mar. Biol. Ecol., 12, 79-102 (1973).

20) B. Kuipers: On the tidal migration of young plaice (Pleuronectes platessa) in the Wadden Sea. Neth. J. Sea Res., 6, 376-388 (1973).

2) H. W. van der Veer and M. J. N. Bergman: Development of tidally related behaviour of a newly settled $\mathrm{O}$-group plaice (Pleuronectes platessa) population in the western Wadden Sea. Mar. Ecol. Prog. Ser., 31, 121-129 (1986)

22) I. Hirata and H. Nomura: Effect of stocking with smalysized artificial seedling for additional recruitments onto $O$ group Japanese flounder viewed through sample boat survey. Saibaigyogyo Gijutsu Kaihatsu Kenkyu, 18, 25-34 (1988). (in Japanese)

23) R. Berghahn: Untersuchungen an Plattfschen und Nordseegarnelen (Crangon crangon) im Eulitoral des Wattenmeeres nach dem Übergang zum Bodenteben. Helgol. Meeresunters., 36, 163-181 (1983). 